\title{
Arguing with Artefacts, Biofacts and Organisms: Barber's Advocacy for 1820 Settlers' Supremacy and Land Rights
}

\section{Barber's Construction of Africans}

In the mid-1830s, the heated public debate ignited by the Sixth CapeXhosa War about Xhosa-British relations saw the Bowkers' attitudes shift. During this period, the twin myths of vacant land as well as Xhosa aggression supposedly leading to the outbreak of the Sixth Cape-Xhosa War were established. ${ }^{1}$ Barber's brothers played a significant role in reinforcing this biased point of view with occasional papers published in the Graham's Town Journal. William Monkhouse Bowker (1803-1876), Barber's second oldest brother, wrote similar contributions in the local newspaper, as had his deceased older brother, John Mitford. ${ }^{2}$ Andrew Bank has shown how liberals' favourable attitude towards indigenous peoples sparked a fierce counter reaction from the British settler community-on the colony's eastern frontier in the 1830s and 1840s - who could read theories of scientific racism and biological determinism. ${ }^{3}$ This growing denigration of and hostility towards the amaXhosa was not a discussion limited to men, as letters from Barber's mother demonstrate. ${ }^{4}$

Barber's attitude towards Africans hardened after the Eighth CapeXhosa War and particularly in Kimberley. In the War, the Barbers and Bowkers lost virtually everything they had owned and found it difficult to cope with their renewed loss of property and status. While living in Kimberley in the 1870s, the economic difficulties which her family faced (see Chap. 8) as well as the sheer number of Africans she encountered for

(C) The Author(s) 2019

T. Hammel, Shaping Natural History and Settler Society, Cambridge Imperial and Post-Colonial Studies Series, https://doi.org/10.1007/978-3-030-22639-8_7 
the first time left her feeling anxious. Due to the mineral revolution during which whites required cheap and subservient black labour to mine for their conglomerates without the labourers' claiming rights to the fortunes made, there was an increasing need to clarify the ideological implications of race so that African miners would accept their place within a society moulded along imperialist and racial-supremacist lines. ${ }^{5}$

In Kimberley, Barber was best known for her articles and poems which contrasted 'civilized Europeans and uncivilized Africans'. 6 These were published in the Cape Monthly Magazine (CMM) and were addressed at fellow settlers. By the 1870s, however, it had become clear that this generalist journal could no longer satisfy scholars conducting detailed research on literary works, in art history and in the sciences. Two separate societies emerged to fill this gap, the South African Fine Arts Association (1871) and the South African Philosophical Society (1877). The formation of the latter was part of the trend towards the differentiation of academic disciplines and the professionalisation of the sciences in South Africa. ${ }^{7}$ Unlike smaller regional journals and societies which experienced difficulties in recruiting sufficient members and subscribers, these large societies formed equivalents to the Linnean Society and Royal Society in England. From 1878, the Transactions of the South African Philosophical Society (TSAPS) were published, and the society soon became the country's premier general scientific institution. ${ }^{8}$ Remarkably, Barber's articles in the TSAPS did not differ in rhetoric from those which she published in the CMM, which may indicate that the readership and authorship of the two publications largely overlapped and shared the same ideological convictions.

From the 1870s, CMM articles in general became more and more derisive of Africans. ${ }^{9}$ White settlers were presented as victims-not oppressors - and their sufferings were explained at length. Such sentiments were shared among many settlers in the British colonies, who considered themselves at home on the land, while the local indigenous population were aggressive assailants. ${ }^{10}$

As an erratic example, in Barber's 1873 article on 'The Dark Races of the Diamond Fields', she suddenly shifts from two opening paragraphs on African mine workers to a discussion of flies. She argues that the English fly is 'the best-behaved': coming 'from highly-civilized Europe' it has 'superior manners to its swarthy savage South African brethren'. ${ }^{11}$ But black flies now predominated, despite bluebottles, house and gad flies also occurring in great numbers. ${ }^{12}$ Black flies felt at home, appropriated dwellings, stole liquor, were always on the lookout for food and were 
omnipresent in troubling Barber and her white compatriots-an analogy to black mine workers, and white diamond diggers' strained relations with the Africans present. ${ }^{13}$ Meanwhile, the common black crickets of Griqualand West served as an analogy to the local Griqua people, asaccording to Barber-the crickets (Griqua) were a constant irritant and terror for their singing and destruction of the land. ${ }^{14}$

The article ends in a series of rhyming couplets of a poem entitled 'The New Rush Flea'. ${ }^{15}$ According to the South African literary critic Jeanette Eve, Barber had written these verses for the amusement of herself and her friends and betrayed no poetic talent in the process. ${ }^{16}$ In this poem, Barber uses the metaphor of the flea to describe African mine workers and thus goes beyond a dichotomy between white 'civilisation' and African 'barbarism' to describe the differences between the races. ${ }^{17}$ The short life expectancy of fleas, their lack of an abdomen, their slowness in flight and weak defence mechanisms against danger also made them suitable metaphors to denigrate the bodies of Africans. Yet despite their alleged physical inferiority, Barber had strong anxieties:

I dread the solemn hours of night;
I dare not e'en put out the light;
Surrounded by the shadowy foe,
The hours of rest are hours of woe,
Although their "face I never see,"
Most vampire-like they fix on me. ${ }^{18}$

Besides her paranoid feelings, she saw their relations as an all-encompassing struggle. She found herself in a constant battle against the black enemy. ${ }^{19}$ In the entire article and its accompanying poem, Barber presents African mine workers as non-human and thus only further fans her readers' racist sentiments.

The years 1877 and 1878 were turbulent years for the Barbers. They were unhappy in Kimberley, due to a lack of economic success, yet they could not return to Albany due to the Ninth Cape-Xhosa War (1877-1879). Barber was afraid that her brother James Henry would have to return to Basutoland as he had been acting as the high commissioner's agent there from April 1868 to May 1870 after the British annexation of the territory. ${ }^{20}$ He was engaged in the Ninth Cape-Xhosa War instead. ${ }^{21}$ Barber's correspondence suggests that she was exhausted and particularly tired of the endless talk of war: 
I wish the world would learn to live quietly without wars, I hate wars. How fearfully the Turks and Russians [in the Russo-Turkish War (1877-1878)] are watching each other just now, and all the world looking on and taking notes, and making pictures of these ruffians, the Illustrated and the Graphic have "gone in" for a series of the most murderous pictures that were ever printed, I am sick of them, page after page of dead mens [!] legs, and arms, and heads. \&c. \&c. [!] we are fast returning to barbarians if such pictures entertain an enlightened public! ${ }^{22}$

However, it was not local but overseas wars which riled her moral senses, and she was less disturbed by the act of war itself than the media sensation mongering which surrounded it. At the Cape, she rarely observed the immediate results of war first-hand, and war scenes were seldom depicted in her writings. Besides, it was not until the Anglo-Zulu war in 1879 that George Taylor Ferneyhough became the first South African photographer to accompany troops into the battlefield. ${ }^{23}$

However, the scenes which Barber described in the quotation and those which she had witnessed at the Cape all the more inflated her belief in 'the survival of the fittest' in the struggle for life. When she left Kimberley in 1878, Barber commented in her travel journal how 'some of the existing races who still [sic!] inhabit the continent of South Africa have made but little progress in the scale of civilization, through the long ages that have passed away', ${ }^{24}$ an aside which is symptomatic of her wish to expel them and her exterminatory leanings.

Barber's article on 'Locusts and Locust Birds', which was read to the South African Philosophical Society on 27 August and 30 September 1879 and published in TSAPS in 1880, was intended to affirm white supremacy and British superiority. While ostensibly a paper on birds' dependency on locusts, ${ }^{25}$ Barber attempted to legitimise the actions of British settlers and what she perceived as their right to land.

In 1885, the same article was read before the Grahamstown Natural History Society-not to inform white settlers on birds and locusts but to self-affirm their feeling of supremacy. ${ }^{26}$ Barber employed different animal species as metaphors for the British and Africans. The British were birds, the Africans locusts. Locusts would retreat into the interior, where they lived a precarious existence and merged with other locust swarms-analogous to the Khoekhoen and San-and left the land they had originally populated to the locust birds. ${ }^{27}$ At the same time, the article generalises individuals into ethnic groups but constructs a nuanced picture of the 
social hierarchy Barber imagines among African ethnicities. These descriptions do not include references to biological aspects, but solely to sociocultural behavioural traits which, she argued, justify the unequal distribution of power along racial lines. She imagines a social hierarchy with the amaXhosa at the top, followed by the Sotho, Batlhaping (of the Tswana), Griqua, Khoekhoen and Ba-Kalahari. ${ }^{28}$ The nomadic San are at the lowest rung, as from Barber's point of view, they do not have the capacity to think about the future and are naively happy to live from hand to mouth. ${ }^{29}$ The next subsection offers an in-depth analysis of this article and Barber's construction of Afrikaners.

In her travel journal, Barber also used plants as a means of expressing social hierarchy and to promote Cape Colonial nationalism. For instance, she compared a Xhosa man to a huge succulent plant in reference to his 'domestication'. Influenced by Atherstone's research on lunatic asylums in Britain, Europe and at the Cape, she visited such an institution on Robben Island where she encountered a Xhosa man whom she compared to a Mexican species of cactus which have been common in the area around Makhanda (Grahamstown). In analogy to the American prickly pear (cactus opuntia), which Barber no longer considered to be an invasive plant at the Cape due to its domestication, acclimatisation and adapted thorns which resembled those of indigenous plants, Barber felt this Xhosa man had been silenced and successfully assimilated into British settler culture. She sarcastically added that if some exasperated, thrice ruined frontier farmers had seen this Kafir, they would have exclaimed "Oh that they were all as good and quiet as he is". ${ }^{30}$ To domesticate, then, also carries 'as one of its meanings the action "to civilize"'. Through often violent 'rituals of domesticity', plants and people were 'inducted through the domestic progress narrative into a hierarchical relation to white men'. ${ }^{31}$ The expression of social hierarchy for Barber promotes the systemic civilising of 'inferior' species.

Barber, thus, did not subscribe to the eugenic views of Ernst Haeckel who called for the killing of the sick, weak and handicapped to promote the survival of the fittest of the species. Instead, she shared the opinion of William Porter, the first chancellor of the University of the Cape of Good Hope (1876-1880), who argued that Christians should not kill the sick and weak, but build hospitals for them. ${ }^{32}$ Yet Barber did not fully agree with Porter's supposedly advanced or progressive Unitarian Liberalismwith its strong beliefs in charity and the fundamental equality of all human beings-when it came to the amaXhosa and the Africans she experienced as potential threat. 


\section{Barber's Use of Metaphors to Emphasise Afrikaners' INFERIORITY}

Barber and her extended family initially had enjoyed good relations with the Afrikaners in Albany, but over time developed anti-Afrikaner sentiments. Two of Barber's brothers got married to two Afrikaner sisters in 1827 and $1836 .{ }^{33}$ As her private correspondence did not include mentions of them, she was presumably not in as close contact with them as she was with her other relatives. Relations between 1820 Settlers and Afrikaners deteriorated and led to the Great Trek, Afrikaners' north-eastward emigration away from British administration in the Cape Colony during the 1830s and 1840s. Some of the communities had already led an isolationist and semi-nomadic lifestyle before the trek to evade the developing administrative complexities in Cape Town. Yet the Afrikaners had particularly been alienated by the 1834 decision to abolish slavery in the British colonies.

Barber for the first time openly voiced her anti-Dutch feelings in 1847, when she wrote to her oldest brother John Mitford with the view that there were too many Afrikaners who were envious of the English and their achievements after visiting a farm near Graaff-Reinet. ${ }^{34}$ Entries in the journal of Sophia Beddoe, governess to Bertram's children, indicate that the Bowkers' anti-Afrikaner sentiment had become quite strident by $1864 .^{35}$

In the 1870s, prior to the First South African War (1880-1881), the Afrikaners were more heavily criticised by the British settlers. The CMM presented the stereotypical Afrikaner as an anti-progressive and 'antimodern variant of the European noble savage'. Their lack of regard to time and industry, their subsistence lifestyle and disinterest in material progress was seen as the very opposite to British vigour and determination. Yet the $C M M$ was never anti-Dutch per se, with liberal Anglophones prepared to include the supposedly advanced or progressive Afrikaners within a common Anglo-Dutch Cape colonial identity. ${ }^{36}$

In 'Locusts and Locust Birds', Barber referred to Afrikaners as voetgangers, young locusts in the wingless stage. Hierarchically, the Afrikaners were situated between the 1820 Settlers and the amaXhosa. The voetgangers are said to lie dormant and passively await a brighter future while leaving devastation and ruin in their wake. The damage they caused in the process, she argued, was worse than that wrought by the Imago locuststhe amaXhosa - who did not leave the land completely bare. ${ }^{37}$ The voetgangers had lived on the Fish River heights, but left the neighbourhood 
when the birds came along taking a northern course into the interior, in analogy to the Great Trek. ${ }^{38}$ Voetgangers were

a terrible scourge to the country wherever they occur, clearing off fields of corn and gardens of vegetables, and leaving devastation and ruin in their wake - in fact, destroying every green thing, not only in the cultivated fields, but throughout the length and breadth of the land, to the utter destruction of all pasturage, leaving no food for cattle. They are considered worse even than the Imago locusts themselves. ${ }^{39}$

Barber describes the destruction of the land inflicted by the Afrikaners and voetgangers in an identical way, as a comparison of the above passage with the one following taken from her travel journal (c. 1879) of her journey from Kimberly to Durban via Cape Town shows:

The homesteads of the rude uneducated Boers are all alike throughout this country. They are pictures of squalid wretchedness and discomfort, entirely without the improvements which Civilization should carry in her wake; not that I have much faith in civilization, it may be a mistake altogether, however, we expect from it, and, I fear, reap but little. Let us bear in mind that these Boers are included in the list of civilized men. Has the country, I wonder, benefitted by their possessing it? They have certainly acted as pioneers, they have cleared the way, driven out the original inhabitants! Before their long rifles the magnificent herds of antelopes have almost entirely disappeared, together with the elephant, the buffalo, the giraffe, rhinoceros, hippopotamus, lion and the wild Bushman with his poisoned arrows: all are gone, even the reed beds which gave them shelter, which in former times fringed the margins of our rivers; rivers which were once running streams, but are no longer so; the scrubby, bitter, Karoo bush has taken the place of the once charming fields of grass, and other valuable pasturage plants. Such is the result of civilization, and the love of greed, of over-stocking and ruining a fine country: and after all this, what have we left? $[\ldots]{ }^{40}$

She portrays voetgangers as swifter still than adult locusts, reflecting her conviction that Afrikaners are superior to Africans. She also sees the voetgangers' colour as gradually changing as they assimilate to their adopted homeland. ${ }^{41}$ Among humans, this process was called 'going native' or 'Verkafferung', a term that the Germans adapted from Afrikaans in SouthWest Africa to describe the loss of distance and an over-assimilation of the colonial population to the locals. Barber highlights how the intellectually 
vastly superior British settlers were thereby left with the responsibility of protecting nature by restraining its human foes, the Afrikaners and Africans alike.

Through descriptions of landscape in her travel journal, Barber offered further arguments for the inferiority of Afrikaners. During a period of political upheaval in the region during the Anglo-Zulu War and shortly before the First South African War, Barber repeatedly emphasised the stark contrast between indolent Afrikaners living in isolated, wild settings and British settlers who had built schools and houses of (what she experienced as) admirable architecture in 'park-like and picturesque' scenery which testified to their industriousness. ${ }^{42}$ In contrast, she observed the typical homesteads and kraals of Afrikaners' and the customary Xhosa dwellings and dams with a sharp eye for their respective failures in agriculture, gardening and cultivation. She criticised Afrikaners for planting invasive species such as willow trees, American aloes, fig trees and blue gum trees in their gardens ${ }^{43}$ and expressed disappointment that civilisation had brought so little for the uneducated Afrikaners whose homesteads all looked alike. She henceforth excluded them from 'the list of civilized men'. Yet, she differentiated between uneducated and educated Afrikaners. The latter she praised for their Dutch Reformed Church buildings and farmhouses that she found 'homelike' and reputable in prosperous-looking district towns such as Victoria West on the bank of the Brakrivier in the central Karoo region. ${ }^{44}$ Barber clearly distinguished between Afrikaners in remote, rural areas, whom she deemed 'primitive' and backward, and urban, progressive ones. Her correspondence and scientific collaborations were nevertheless curtailed to English-speaking partners.

\section{Thinking with Plants: Barber's Hostility Towards Australians/Britons and Botanical Nationalism}

Besides Afrikaners and Africans, Barber was particularly critical of Australians. Her disdain extended to Australian insects and plants, and she accused Australian blue gum trees, for example, of being 'interlopers' which 'harrowed up' her 'African feelings' ${ }^{45}$ Similarly, in her mind, the Australian beefwood was gloomy and apt to emit a funeral sound in the wind which caused any passers-by to contemplate suicide.

In the 1870s, there were many Australians on the diamond fields, and Barber possibly linked her family's failures at diamond digging to them (see Chap. 8). Moreover, she seemed resentful that the colonial 
government had employed the Australian Edward John Dunn as Cape government geologist, instead of an 1820 Settler from her own network. She refused to refer to research by Australians and eventually only reluctantly did so upon Trimen's urgings. The Cape Colony and Australia were competitors as both wanted to be the superior colony and the first in the Southern hemisphere to give rise to scientific revolution or innovation.

Yet, Barber was equally critical of Britons who had arrived much later than the 1820 Settlers and were quick, for example, to plant pine trees to the exclusion of indigenous trees, which she considered to be better adapted, 'more varied and interesting' ${ }^{46}$ Barber also made sure to stress 1820 Settlers' superiority and the supremacy of their scientific contribution. She emphasised that they had far superior knowledge of South African plants than that displayed by European or Australian visitors, whom she disparaged as unaccustomed to finding the secret spots of plants and often incapable of spotting a single abundant plant species on their travels. ${ }^{47}$

Barber also expressed 1820-Settler values through comments and observations on plants. The wild fig grows out of other trees' hollow trunks and forms a trunk of its own, a process which served as an analogy for original 1820 Settlers laying down roots in a foreign land and making it their own. ${ }^{48}$ Similarly, the grapple plant, which spreads its seed by clinging to the fur of animals, served as a metaphor for British settlers, who were steadfast in defending their locations in the struggle for life, or the dispossession of land respectively. She admired the sprigs, in particular, for being tough, unbreakable and (re)bendable in any direction. ${ }^{49}$ Barber admired invasive plants that courageously were able to cling to life in their new homes, withstood wind and weather, and displayed superior persistence to indigenous plants and people - an analogy to the, in her mind, well-adapted, brave 1820 Settlers who withstood the furies of the CapeXhosa Wars. ${ }^{50}$

Barber was underlining the uniqueness of Southern African flora several years before Cape Town-based botanist Harry Bolus (1834-1911) made the now famous claim that the number of different plant species at the Cape far exceeded that of all other known regions of the world. This claim was preceded by the ones uttered by Sir John Barrow, Karl Wilhelm Ludwig Pappe, William Henry Harvey and the brothers Carl Friedrich and Johann Frantz Drège, yet-unlike the men colleagues who preceded her-Barber's was the first in the context of the raising Cape nationalism. Bolus wished to awake 'patriotic South African sentiment' in the period of 
the Second South African War. While a strong identification with local flora was responsible for the awakening of a wider South African nationalism in the $1890 \mathrm{~s}$ and the first decade of the $1900 \mathrm{~s},{ }^{51}$ this botanical nationalism first gained momentum in the late 1870s.

The link which Barber drew between the natural and social worlds thus occurred primarily at a metaphorical level. In contrast, the discipline of archaeology allowed Barber to address her political concerns more directly, particularly as she was at the very centre of a scientific network which evolved around the first archaeologists at the Cape. ${ }^{52}$

\section{Reasoning with Artefacts and Biofacts: Theories FOR Appropriating Territory}

Barber and her older brother Thomas Holden Bowker were largely responsible for the birth of archaeology at the Cape. ${ }^{53}$ The emerging discipline was inextricably linked with the annexation of land, and Bowker's presence in parliament during the 1857-1858 session was of particular importance in this regard. After his success as commandant of burghers at Whittlesea (1850-1853), for which he was given an award and testimonial, Bowker enjoyed great popularity in Albany. He became an acting member of the House of Assembly (the lower house) and the legislative council (the upper house) of the Parliament of the Cape of Good Hope (founded in 1853) for Albany, Victoria East and Queenstown from 1854 to 1863 .

Since 1835 he had been concerned with 1820 Settlers' compensation claims for Cape-Xhosa War losses and had been known in Albany under the cognomen of 'Compensation Bowker' ${ }^{54}$ After the Eighth Cape-Xhosa War, he was part of a commission which distributed farms to supposedly deserving burghers who had fought against the forces of the Xhosa paramount chief, Sarili ka Hintsa. In family lore, Bowker is remembered as selflessly waiting for the last piece of available land to be distributed before claiming his share, which would ultimately prove unsuitable for farming.

On experiencing ensuing financial difficulties, ${ }^{55}$ he wrote a memorandum in which he listed all his achievements ${ }^{56}$ : he declared himself unappreciated and declared the achievement recompense for his deeds as an overlooked national hero his ulterior aim. Thanks to the government's lack of a frontier defence plan, he argued, he had had to sacrifice his career and fortune to protect his compatriots. He now demanded land, but not just any land: he demanded Theopolis, which had been a London 
Missionary Society (LMS) station since 1814 and was situated to the east of Grahamstown. ${ }^{57}$ This site was of symbolic importance as Bowker was strongly opposed to missionaries in general and those who had lived and worked at Theopolis in particular. ${ }^{58}$

The Scottish missionary Dr. John Philip (1775-1851), superintendent of the LMS stations in South Africa, had frequently criticised the colonists and the colonial government's treatment of the autochthonous population, and Bowker was expressly opposed to him. While the House of Commons in London had adopted Philip's recommendations for the expansion of civil rights to 'indigenous and coloured people' at the Cape and had forced the colonial government to abide by his suggestions, his unpopularity among the settler community grew after the controversial Ordinance 50 was passed in 1828 which granted Khoekhoen and San free movement on the labour market. According to Philip, however, Ordinance 50 ensured little beyond the continued availability of Khoekhoe wage labour for settlers. ${ }^{59}$ The Eighth Cape-Xhosa War was a catastrophe for the LMS: the Theopolis mission station had been broken up, the Philipton station burned to the ground and the Kat River Settlement was destroyed before white settlers were able to purchase much of its land.$^{60}$ Had Bowker received former LMS land, this would have been a significant victory for the settlers in this ideological battle as well as a touchdown of revenge for Bowker.

His memorandum was discussed in Government House on 31 March 1858 by Sir George Grey, who was the governor of the Cape Colony from 1854 to 1861 . Bowker's was one among 400 applications for land, mainly from British settlers, discussed at the time. ${ }^{61} \mathrm{~A}$ committee questioned witnesses and resolved to report on the matter to the House before adjourning. Ultimately, the government did not recognise any of Bowker's claims, but Grey offered to lend him 100 pounds. ${ }^{62}$ As Bowker's hopes for financial recovery through land were dashed, he was turning to a quest for archaeological artefacts trying to find a reason why white settlers like him had a reason to occupy the land.

In March 1858, during the same parliamentary session, he had visited Edgar Leopold Layard, director of the South African Museum in Cape Town. Bowker entered Layard's office as the latter was unpacking a collection of flint artefacts from Copenhagen. Layard must have learned about these finds, which he had ordered for a display planned in Cape Town, through his eldest brother, Austen Henry Layard, who had excavated Nimrud and Niniveh in the Middle East and had uncovered the library of 
Ashurbanipal in 1851. Bowker surmised that these Scandinavian finds resembled the stone arrowheads which he had found in his youth.

According to The Lower Albany Chronicle, the then twenty-year-old Bowker, who had been living at the Cape for seven years, had found flake points which he used as arrowheads on hunting expeditions in December 1827. ${ }^{63} \mathrm{He}$ had promised to send these to Layard, as the latter reported, if the barn, where Bowker had stored them on the farm Tharfield, 'had remained undisturbed, and had escaped the ravages and burnings of [Bowker's] foes, the Kaffirs' in the intervening decades. ${ }^{64}$ After his return from Cape Town in 1858, Bowker conducted a search at the mouths of the Kowie and the Kleinemond, two small rivers which opened on to the beach on his land, and found further stone implements. Nonetheless, public recognition continued to elude him, and he was not elected president of the Orange Free State in 1863, even though he had been asked to be a candidate and supported by the press. ${ }^{65}$ Bowker decided to seek fame in different ways.

For one of his attempts, he sent a letter on his finds to Layard, who in turn forwarded it to Professor Richard Owen at the British Museum in London. In this letter, Bowker maintained that the stone implements which he had found were produced by the same people who had made those he had seen from Copenhagen. Some of the perforated implements he had gathered bore the marks of strikes from a hammer or a long, hard pebble, an act of which he did not believe 'a stalwart savage' capable; as Bowker argued, Africans had no knowledge of any skills besides shooting. He further claimed to have found other, less complex implements which bore the mark 'of the savage whose ideas went no further in the art of stone cutting than is necessary for chipping a flint' ${ }^{66}$

In search of support for his theory that these implements were indeed made by originally white people populating Southern Africa, Bowker first turned to his sister Mary Elizabeth who had by then become a botanist, entomologist and ornithologist. She replied in 1865 that she did not believe that the original inhabitants of the region had been white; for if they had been, as she argued in a staunch Social Darwinist manner, they would not have subsequently vanished. ${ }^{67}$

Bowker then contacted former governor of the Cape Colony and then governor of New Zealand, George Grey, who held a wide interest in prehistory and ethnology. ${ }^{68}$ In 1838, Grey had been the first to document rock art in the Kimberley region of Australia, arguing that it was scarcely 
probable that a self-taught Aborigine could have created these paintings and that their true origins were open to conjecture. The Aborigines whom he had questioned about the matter meanwhile never claimed their ancestors to be the original artists of these paintings, but that 'the moon, who was a man' had created them, something which Grey took as a reference to a white man. Like Bowker, Grey also argued for two distinct styles of cultural artefacts. While the rock art near the coast was 'nothing but the rudest scratches', the more complex drawings, which culminated at the furthest point from the sea, however, pointed towards a lost tribe of whites in the interior. ${ }^{69}$

In a letter to Grey, Bowker argued that because the first European visitors had not seen the arrow and spearheads in use and the contemporary Khoekhoen did not use them, they had to be the only remaining evidence of the original inhabitants of the Cape, who would have been 'far anterior to the advent or immigration of' the amaXhosa, Khoekhoen or San. ${ }^{70}$ In line with Jean-Jacques Rousseau, who had claimed that 'savages' had never used tools, and Scottish anatomist, ethnologist and medic Robert Knox's conviction that the Cape had remained unaltered over time, ${ }^{71}$ Bowker recorded that he had not seen any locals using tools to make fire or obtain honey as he himself had always done. ${ }^{72}$ As he considered Africans to be 'living fossils' who had not developed since the prehistoric period, he assumed that the San would still use such Stone Age tools if they had once made them.

By the 1870s, archaeological evidence allowed for two fluid and interwoven positions on the Khoekhoen and San and their place in Cape society: an admiration for their rock art and an acknowledgement of the importance of preserving it juxtaposed with the conviction that, as inferior peoples, the Khoekhoen and San were doomed to extinction. ${ }^{73}$ Their expected demise was linked to an urgent quest to put them and their artefacts on display-whether in zoological gardens as part of live ethnological exposition, so-called Völkerschauen, or in museums-before they were gone forever.

That the San could have produced those so-called Bushmen stones was unthinkable for Barber. When on the Vaal, the San were no longer present; they had 'made room for civilization', as she euphemistically put it. Their ancestors from prehistoric times could not have made holes through these hard stones, she believed, as they had probably not been hardworking and were 'not an improvable people'. ${ }^{74}$ She thus employed the idleness 
trope, widespread among settlers, which constructed a distinction between diligent British settlers and idle, anti-modern, anti-progressive locals and argued that they had not evolved. ${ }^{75}$

Roland Trimen seems to have criticised Barber's theory and to have referred her to publications by the English traveller Burchell and the Australian geologist Dunn. ${ }^{76}$ Burchell had seen a San woman with three sticks upon which 'Bushmen stones' were fixed near Hopetown in 1812. She had used these either for walking or for digging wild roots. ${ }^{77}$ In 1873 , Dunn published an article in which he claimed to have been told by San people that they had been perforating stones until recently. $\mathrm{He}$ also observed a San woman in Struits Pits at the Sak River, close to Brandvlei in the Karoo, who had been using a stick for digging and who told him that hard, pointed stones were used to perforate stones. This, Dunn reported her saying, was being done from both sides until the holes met in the centre. ${ }^{78}$ In 1879, Barber referred to both Burchell and Dunn in her travel journal when she described how the San and the 'Koranna' used sticks for digging. ${ }^{79}$

Yet, Barber drew together a host of universalising observations in an attempt to undermine arguments about the uniqueness of San cultural practices and dispossess the San people of their cultural achievements. She devoted much attention in her travel journal to report on similar findings by Darwin in India and Giovanni Ignazio Molinas in Chile. In a CMM article in 1871, she claimed that early humans had used bored stones for similar purposes all across the world.$^{80}$ She argued that some of the existing races at the Cape had progressed little on the scales of civilisation since and were still using stone tools. The logical conclusion of her theory was to argue for the common ancestory of all humans. However, according to her, this had no implications of present-day equality across the species. Barber read in stone implements 'the simple history of a type of the human race, which was but slightly removed from its poor relations who dwelt in trees'. ${ }^{81}$

Even so, Barber's interpretation shifted over time. The knowledge that Barber produced in this interdisciplinary endeavour was both ever-changing and speculative in nature. Indeed, its very fluidity could serve to continuously legitimise contemporary colonial practices and policies and their accompanying aims of settlement and dispossession by recourse to perceived and self-constructed racial hierarchies. In 1877, Griqualand West was incorporated into the Cape Colony, and Barber justified this annexation through her interpretation of the 'Bushmen stones'. She had 
changed her mind and now perceived them as evidence for the theory of an original white population having inhabited the area after all.

Barber had discussed this interpretation with Charles Warren, who during his time with the Royal Engineers in Palestine had been commissioned by the Palestine Exploration Fund to carry out archaeological research in the region, explicitly on the Temple Mount (Jerusalem). Warren now was an officer in the Royal Engineers squad which was working on defining the boundary between Griqualand West and the Orange Free State, an independent Boer sovereign republic. ${ }^{82} \mathrm{He}$ reported to Barber that he had found similar bored stones in the valley of Jehoshaphat-presumably the Kidron Valley on the eastern side of the Old City of Jerusalem-with Hebrew inscriptions. ${ }^{83}$ In response, Barber suggested that white people of Jewish descent had perforated the Griqualand West stones. Having presumably read Alfred Russel Wallace's argument that Jews retained the skin colour of the Germanic races everywhere, ${ }^{84}$ Barber believed a lost tribe of Jews may have lived in Southern Africa millennia ago. The ancient Kingdom of Israel consisted of twelve tribes, and when the kingdom collapsed in 722 B.C.E., the Assyrians were widely believed to have exiled ten tribes who subsequently disappeared from historical records. This reflected the popular discursive trope in the Victorian period that the ancient ancestors of the British people were the lost tribes of Israel. ${ }^{85}$

Barber's explanation is not dissimilar to German explorer and geographer Karl Gottlieb Mauch's theory concerning the ruins of Great Zimbabwe. In his report to Justus Perthes' Geographical Society from September 1871, he speculated about the site's possible association with the biblical King Solomon and the Queen of Sheba. ${ }^{86}$ He argued that the structures had been built to replicate the Queen of Sheba's palace in Jerusalem ${ }^{87}$ and believed a wooden lintel, which he found at the site, was made of Lebanese cedar brought to present-day Zimbabwe by Phoenicians. ${ }^{88}$ Inevitably, Mauch believed that the contemporary Shona inhabitants' ancestors could not have built these structures. The Sheba legend soon became pervasive in the white settler community and a legitimised reason to lay claim to the gold found in present-day Zimbabwe. In a strange twist of logic connecting antiquity, culture and land, indigenous African peoples thus became transient interlopers wedged between earlier and later possessions of the land by whites. ${ }^{89}$ Bowker and Barber in the same way erase the history of contemporary Africans by positing a vanished white Jewish presence which only the settlers could revitalise. 
Prospectors such as Cecil John Rhodes, who visited Great Zimbabwe for the first time in 1891, informed Lobengula, the leader of the Ndebelewho had established his kingdom in present-day Zimbabwe after being driven north by the Afrikaners in 1837-that "the "ancient temple" which the "Great Master" was visiting had once belonged to white men'. ${ }^{90}$ That Africans would never have been capable of initiating such labour was common knowledge, J. Theodor Bent argued, an English author and explorer who went on an archaeological expedition to Great Zimbabwe sponsored by Rhodes. As he regarded Africans as nomads and anarchists, Bent deemed them incapable of organising themselves in the social structures required to execute such a task, and he concluded that Africans could only have built Great Zimbabwe as slaves of a higher civilisation. Scottish-born South African ex-civil servant and politician Alexander Wilmot, then the leading textbook writer at the Cape, whom Rhodes paid for archival research of descriptions of Zimbabwe in European libraries, argued that Southern Africa was a white man's land in which the only role for Africans was that of cheap labourers. ${ }^{91}$

Despite that, settlers also perceived indigenous people as irritants intruding on and disturbing their peace. ${ }^{92}$ Settlers disregarded the histories that preceded their arrival and considered themselves to be the first real inhabitants of the land on which they settled. ${ }^{93}$ As the literary scholars Anna Johnston and Alan Lawson argue, a settler narrative follows two goals: it aims to suppress and efface the indigene, while, conversely, also seeking to indigenise the settler in the founding and growth of culturalin this case Anglophone Cape Colonial-nationalism. ${ }^{94}$ Archaeological discourse in Southern Africa is a clear example of how these two aims supplemented each other.

As a system of knowledge, the British Empire, in this case, articulates itself and is negotiated through relevant scientific disciplines and institutions such as anthropology and phrenology which held crucial roles in colonial society. The Bowker siblings also collected contemporary tools because there were no clear lines between anthropology and archaeology and no professionals in these fields yet. They also did so because they thought that Africans were developmentally speaking millennia behind and thus historical artefacts themselves. For example, Barber's brother Octavius Bourchier Bowker (1816-1899) held a great interest in weapons. He was a partner in the weapons firm Hayton and Bowker and traded firearms with Afrikaners in the Orange Free State. As a burgher, he served in the Senekal's War of 1858 and the Sequiti War (1865-1866, 1867-1868) 
against the Sotho and collected many of their 'war implements'. He sent a letter that has not survived to Barber, who was then living on the farm Highlands near Grahamstown and mentioned it in a letter to Trimen. Barber subsequently contacted Trimen in Cape Town, inquiring whether the Sotho 'war implements' were worth sending to the Paris Universal Exhibition, which was scheduled for the following year. Trimen's reaction is not known, but we can assume he helped Barber sending them to responsible actors who displayed these 'assegais, clubs, and shields of Basutos' in Paris in 1867..$^{95}$ To all appearances, Barber intended to demonstrate the primitive developmental stage at which the Sotho found themselves, and declared how the 'war tools remind one of the stone arrow heads' of the San who she imagined as the lowest representatives of the human species.

This is another revealing example of visible concealment; in the process of collecting these artefacts and offering them to urban, metropolitan institutions, the original ownership of the objects is stripped in various ways. Most obviously through the very act of collection, the owners of the weapons are deprived of their tools. The drawing, arranging, inscribing and naming of the artefacts by Bowker and Barber then further remove them from their Sotho context and allow for their dissemination and display among and within the Northern networks of knowledge and exhibition. This process transposes them into an entirely new setting, where the histories of their original production, possession and collection are further silenced. Thus freed from their background and history, they are presented as trophies of British supremacy which conceals their true origins.

The Sotho war tools, stripped of any context or history, ultimately satisfied a European public curious for displays of artefacts made and used by indigenous people. Their display at the Paris Universal Exhibition formed part of the same 'entertainment economy' as 'Völkerschauen' or the tours of 'professional savages'. The relationship between such artefacts or 'performers and the public was marked by a distancing that fostered stereotypic attitudes'. ${ }^{96}$

Cape-born and bred, James Henry Bowker-the lepidopterist-was convinced that land inhabited by cannibals should be appropriated. As agent to the high commissioner, he visited the caverns in the Transgariep region of today's Free State province. He thus sent his sister a detailed account of his observations from the excursion which she then remodelled into the paper which was later erroneously published under the name of a 'Mr Layland'. ${ }^{97}$ The letter focussed on the allegations that the Sotho were 
cannibals and Bowker's bewilderment as to why they ate 'their own wives and children' since the 'savages' lived in 'a fine agricultural tract of country, which also abounded in game'. These 'horrible practices of this degraded people' had not been abandoned, he claimed, as he had spotted fresh evidence of human bones. He described how the agriculturally promising area near the Caledon River, including a section of the banks of the Putesana River, had been inhabited by cannibals in the past, and he further claimed there were 'still a good many of the old cannibals in existence' including people who even then lived in caves, for instance 'near the sources of the Caledon River'. ${ }^{98}$

In 1880, James Henry Bowker collected stone artefacts in KwaZuluNatal after the Anglo-Zulu War and reported that he observed Maluti San using stone arrowheads. ${ }^{99}$ In an article in the Natal Witness on 17 April 1880, he argued that the artefacts which he had found at Rorke's Drift and Isandhlwana did not differ from those found at the Cape, in Griqualand West or in the Free State; he thus argued for a white original people populating the entire region. ${ }^{100} \mathrm{He}$ was, thus, in agreement with his siblings.

In 1884, after Basutoland became a British Crown Colony, he published an article, 'Other days in South Africa' in the TSAPS, which was based on the 1868 'Layland' article. In it, he attempted to justify the British annexation of more than half of the territory's arable land in 1871, when the boundaries were fixed. He spurred imperialists into reconquering further agriculturally promising land near the sources of the Caledon River. ${ }^{101} \mathrm{He}$ also reported on how Tswana refugees from the Caledon River valley had been employed on his father's farm and that a boy who had learned English had told him about the barbarian practices of his people. These sections had not been part of the 1868 version, and no other references to Tswana people living on any of the Bowkers' farms could be found. ${ }^{102}$ They suddenly became important as their supposedly cannibalistic and uncivilised practices allowed Bowker to justify the colonisation of their cultivatable land. In his History of South Africa Since September 1795, the settler historian George McCall Theal, whose focus was invariably 'the spread of white settlement and "civilization", and the moral and material progress that accompanied that process', included a renarrated account of Bowker's visit to the cave in July 1868 taken from his correspondence with the high commissioner. It thus earned itself a place in the traditions of settler history. ${ }^{103}$

Besides collecting anthropological and archaeological artefacts and supposed evidence of cannibalism, the Bowkers also collected human remains. 
Barber most likely came into contact with phrenological theory through the medic H. E. Macartney, who had opened a practice in Grahamstown after the Sixth Cape-Xhosa War and spoke widely on phrenology in public lectures. ${ }^{104}$ Barber and Thomas Holden Bowker presented some of their finds from the vicinity of the Tharfield farm at the first meeting of the Albany Natural History Society on 11 September 1867. Among these were potsherds, stone tools and fragments of human skulls. The Graham's Town Journal openly reported Bowker's plundering of a young woman's grave-a grave surrounded by others which may have been robbed as well. The dead body, which had been buried in a sitting position, ${ }^{105}$ was most likely of Khoesan or Xhosa origin. It was not mentioned whether this find was a chance discovery or the result of an archaeological excavation, nor whether the young woman had died recently or centuries earlier. As phrenology had died out decades before the 1880s, Barber and Bowker were physical anthropologists.

It is noteworthy that this was the skull of a woman and not the usual male specimen which local and European phrenologists were usually most interested in. For instance, Swiss naturalists Paul and Fritz Sarasin from Basel, who collected skulls in the British crown colony of Ceylon between 1883 and 1886, only regarded men as meaningful representatives of the physical and psychological levels of development of their respective 'race' or 'variety'. ${ }^{106}$ While the difference between zoological 'species' and human 'varieties' was always of a gradual nature to them, gender differences were categorical and absolute. ${ }^{107}$

In 1870, Barber recounted to Trimen that she and her little nephew came across exposed bones while they had been collecting 'specimens' at the beach. They went on to excavate an entire human skeleton. As nobody had been reported missing in the fifty years she had been living in the area, Barber was convinced that the skeleton must have belonged to a shipwrecked seaman. She then added a telling aside on how it could also belong to 'some creature that fell in war', 'but natives are never buried'108 which shows that Barber was ignorant of Xhosa, San and Khoekhoen burial practices. She did not forget the skeleton; in Kimberley, some six years later, she wrote a poem entitled 'Lost' and speculated on the missing person and forgotten life story behind the bones. ${ }^{109}$

It is not known whether this was the only time Barber collected human remains, but the practice was common in the region at the time. ${ }^{10}$ Zurichbased botanist Hans Schinz, who stole and preserved human remains from 
South-West Africa for anthropological collections in Berlin, described in his travel report how he had secretly dissected 'a well preserved corpse of an Omundonga [a person of the Kingdom of Ondonga] fallen in combat' on a wagon roof, rubbed the bone fragments with arsenic soap and exposed them to the sun. When the wind caused the box hiding the bones to fall to the ground, his 'carefully guarded secret revealed itself'. ${ }^{11}$ Schinz was aware of how problematic the appropriation was, but, as he wrote to his mother, 'one has to collect everything'. ${ }^{112}$ Nevertheless, he was careful to hide the skeleton from the eyes of his travelling companions and locals and did not record the reactions of those who witnessed its fall. Yet, there is scant doubt that his actions only brought him distrust, shame and aversion. ${ }^{113}$ Twenty years earlier, on a journey in Australia, the curator of the South African Museum, Edgar Leopold Layard, collected four skulls of Aborigines, which he described as 'trophies'. The only discomfort he recorded during the episode was having to inhale the aromatic balm with which the mourners had rubbed the dead. ${ }^{114}$ It is quite likely that the skeleton which Barber found became part of a collection-she never mentioned what she did with it in the remaining sources.

Barber's collecting practices must be seen in the context of her multiple and competing identities. Barber was a fervent imperialist who constantly hoped that the Cape Colony and the British Empire would expand and who animated her men compatriots to fight for the expansion through her writing. In her poems and letters, she spurred on the violence and conquest perpetrated by British men. One such poem is 'Egypt', written in Grahamstown in May 1885, in which she addressed the British soldiers:

\footnotetext{
'Bright thy history, but not brighter

Than the deeds which now are done, When each bold and valiant fighter

Strives for victories begun.

England's sons know but their duty, Hearts of oak, they scorn to fly

For Egypt, or our Isle of Beauty,

Win the victory - or die.

Onward, onward, all undaunted,

When the bugle calls to war,

When our strong arm most is wanted,

Men of England! There we are. ${ }^{115}$
}

The poem described the Battle of Khartoum, in which the Mahdist forces conquered Egyptian-held Khartoum after a ten-month siege of the city 
between March 1884 and January 1885. All Egyptian soldiers and about 4000 Sudanese civilians are said to have been killed in this battle. Barber was deeply concerned that the fallen general, Charles George Gordon, would be forgotten and wrote this poem to commemorate British heroism in Egypt and Egyptian-held Sudan. The poem was published in The Royal Engineers Journal in 1886 to encourage further British imperial conquest. ${ }^{116}$

Another example of her steadfast imperialism is the following letter which presumably is the only available letter to her husband, written in 1891 shortly before his death, in which Barber wrote that:

There is plenty of fine country in Mashonaland [a region in northern Zimbabwe] and what does it signify whether Rhodes got it fairly or unfairly, at any rate we have as much right to Mashonaland as the Matabeli have, for they were oppressing the Mashonas, which we would not do. They were carrying off their children for slaves, or wives, and taking their cattle too, and all we shall do is to take some of their land, perhaps pay them for it, give them plenty of work, plenty of money, plenty of liquor and, if they will go to the bad why that is their own fault, their destiny and the law of evolution. If people can not [!] hold their own then good bye to the survival of the fittest, that's all. Their destiny is not in our hands, we can not [!] alter their future. The Fingoes are doing well, and they are under our protection. ${ }^{117}$

Barber legitimised British settlers' actions by invoking a social Darwinist discourse which underlined their supposed moral superiority, right to land and righteous acquisition thereof.

Her arguments were reflected in and reinvigorated by her sons', sonin-law's and brothers' imperialist actions. For example, her son-in-law Alexander Cumming Bailie (1850-1903) left his mark as a geographer, land surveyor and fellow of the Royal Geographical Society. Bailie was a grandson of lieutenant John Bailie, a civil servant and Royal Naval officer, who had been the captain of George Rex's brig, the Knysna. Alexander worked in government service as an assistant to Major Owen Lanyon, the administrator of Griqualand West in Kimberley in the 1870s. He then collaborated with Charles Warren in the Department of the Surveyor-General and undertook a survey assessing the feasibility of a trans-African telegraph system in 1877. ${ }^{118}$ As surveyor-general of Griqualand-West, Baillie was sent to Matabeleland in 1876 as a labour recruiter for the diamond mines, but was also tasked with mapping the route and reporting on the economic potential of the areas through which he passed. Travelling via 
Taung and eastern Botswana, he arrived in Bulawayo before travelling back to Kimberley in 1877, a journey of some 1400 kilometres in total. From 1881 to 1884, Baillie acted as a magistrate in Basutoland. Thereafter, having found no employment in the Cape civil service, he moved to Johannesburg in 1885 , where he became a founding member of the executive committee of the Chamber of Mines two years later. ${ }^{119}$ Bailie's and Barber's imperialist ideologies had a deep impact on his brother-in-law and her son, Henry Mitford Barber. This manifested itself, for instance, in 1892 when he wrote an article on the bellows used for iron-fusing furnaces in the vicinity of Pilgrims' Rest and Mac Mac in today's Mpumalanga province. He claimed that the perforated stones served to connect the bellows to the forge. In doing so, the stones prevented the injuries of the horns through the heat of the charcoal. ${ }^{120}$ The stones, however, were neither manufactured, nor used by San. For Bailie, as for his mother and uncle, the San were 'idle' and 'erratic' and with their 'wandering thiftless habits' would not 'devote hours of labour to this work' nor 'carry them from one part of the country to another'. ${ }^{121}$ $\mathrm{He}$ argued that the stones were instead made by 'Shangaris' and Sotho people. ${ }^{122}$ Mitford Barber's article needs to be seen in connection with Barber's, his uncles James Henry and Thomas Holden's arguments for African inferiority and thus 1820 Settlers' rights to land rich in mineral resources. Alluvial gold had been found in Mac Mac, and the town soon became very crowded. It was officially declared a goldfield in September 1873 , by which time the settlement had quickly grown to 1500 inhabitants. In the 1880s, the alluvial gold dwindled and prospectors moved on to the newly discovered gold deposits which later became known as Barberton, where claims were bought up by the end of the nineteenth century. Barberton is named after Barber's nephew Graham Hoare Barber (1835-1888), who had found a rich gold-bearing reef there in 1884. ${ }^{123}$ Mitford Barber argued that the Africans living in the mountains near Pilgrims' Rest and Mac Mac were of various ethnicities, consisting chiefly of 'Shangaris' and Sotho people who had no more right to the land there than British settlers. His argument justified his and his compatriots' mining. Meanwhile, better-funded mining companies started digging deeper. By 1895, three years after his article was published, several of these mining companies amalgamated to form the Transvaal Gold Mining Estates (TGME).

In 1912, Henry Mitford Barber sold his farm in South Africa and bought one at Kyambu, close to Nairobi, Kenya. He named this farm 
Ivanhoe after the protagonist in Sir Walter Scott's novel Ivanhoe (1820), the crusader Sir Wilfred of Ivanhoe from twelfth-century England. As in Ivanhoe, in which the Normans surround the remaining Saxon noble families, Mitford Barber saw himself as being encircled by the Kikuyu people. His wife, Mary Layard (née Bowker), loved the area and wrote a description of their first years in East Africa, which she called 'Pioneering in East Africa'. ${ }^{124}$ In the First World War, their two oldest sons, Ivan and Raymond, served in the campaign in German East Africa (later Tanganyika, now Tanzania) and Portuguese East Africa (now Mozambique). ${ }^{125}$

This short exploration of the Barber family's colonial ties demonstrates the value of examining imperialism through the lens of individual families and transgenerational acts of settlement and dispossession inside and beyond the Cape. South African Empire Studies explore colonialism in the shadow of European imperialism and pay attention to multiple forms of colonialisms and nationalisms, ${ }^{126}$ including South Africa as both colonised and seeking to build its own empire. The Union of South Africa in 1910 has been taken as the starting point in the revisionist historiography of South African imperialism. ${ }^{127}$ Yet, we should go back in time to study colonialisms already in the nineteenth century.

As Barber wrote about insects, plants and archaeological findings, she discovered more about herself and her settler compatriots. She was collecting, interpreting and affirming her self, her imagined community and distancing them from others. ${ }^{128}$ And so, reassessing the genesis of archaeology as a local discipline can contribute to a rethinking of the role of science in South Africa's past. Archaeology and its practices were not created in Europe and subsequently 'diffused' to the South. While it has also been claimed that archaeology originated at the Cape, it is perhaps better to see the birth of the discipline, and indeed most scientific innovations, as a product of many people. Archaeology was born in many areas of the world at approximately the same time-one such area was the Cape. However, some of the settler desires which acted as motivating factors for and structuring elements of early archaeology in the Cape-and other settler-dispossessory societies such as Australia-have not only survived unchallenged in South Africa, but found their way into Northern metropolitan archaeological discourses. ${ }^{129}$ 
As seen in Chap. 3, San collectors and informants' making sense of the artefacts became intertwined with Barber's and the Bowkers' interpretations as well as Bowker family lore. The traces in the remaining sources suggest their important contribution to archaeological knowledge production and the birth of the discipline. Similar contemporary reasoning, such as from German Carl Mauch on Great Zimbabwe or George Grey in Kimberley, the northernmost region of Western Australia, also influenced their interpretations, indicating that knowledge circulated widely and transimperially in the global South as well as within European and extra-European Empires. Understanding and analysing the desires and urgency which fuelled the Bowkers' and other settlers' imaginings of human origins in Southern Africa is still a task for a changing South Africa today and part of a wider endeavour to rethink South Africa's past. The next chapter is a similar invitation to rethinking science as a space in which gender relations were negotiated in an interplay between the Cape, other colonies and the metropoles of the North.

\section{Notes}

1. See (Crais 1991); (Godlonton 1835, 1836).

2. See for example: The Graham's Town Journal, 23 September 1872; 4 October 1872; 3 November 1873; 23 May 1873.

3. (Bank 1996, 392, but see entire article); (Bank 1995). For more on how history was employed by liberals as well as the Cape Dutch and British settler conservatives in their own ways to justify their positions on race, see (Bank 1997).

4. See, for example, Anna Maria Bowker to her brother Bertram Mitford of Horsley, Tharfield, 16 December 1853, CL, MS 1930.

5. (Brantlinger 2003, 44).

6. (Weedman 2001, 5).

7. (Dubow 2006, 119).

8. The society changed its name to the Royal Society of South Africa in 1908.

9. (Dubow 2006, 111).

10. See for example (Curthoys 1997).

11. (M.E. Barber 1873, 379).

12. (M.E. Barber 1873, 378). 
13. (M.E. Barber 1873, 378).

14. (M.E. Barber 1873, 379-380).

15. "The New Rush Fleas", Kimberley, 15 November 1874, in (M. E. Barber 1898, 20-22).

16. (Eve 2003, 185).

17. (M. E. Barber 1871a) from A. M. L. Robinson (ed.), Selected Articles from the Cape Monthly Magazine, New Series, 1870-1876, Van Riebeeck Series Second Series No. 9 (Cape Town: Van Riebeeck Society, 1978), and (M. E. Barber 1871b; M.E. Barber 1873) quoted in (Weedman 2001, 5, 27, 37).

18. (M.E. Barber 1873, 380).

19. (M.E. Barber 1873, 380-381).

20. See (Tylden 1950, 107).

21. From the war, Bowker forwarded a racist caricature full of stereotypes to one of his colleagues that purported to show how the amaXhosa were conspiratory, primitive, naked and addicted to alcohol. See: 'The Chalumna Scare', hand-drawn cartoon in eight captioned episodes app. Featuring episode of the Ninth Frontier War, $80 \times 90$ on back: 'My dear [Walter Ernest] Merriman, I send the enclosed it was done by a policeman named [John Xavier] Stanford, J. H. Bowker \& Kreli War, Chalumna River CP.' ( ) National Library of South Africa: Cape Town Pictures ARA 7954.

22. RES, Trimen Correspondence, Box 18, Letter 102, Kimberley, 26 November 1877.

23. His work resulted in 55 photographs of the war and an album on the post-war journey by the empress of France (1853-1870) Eugénie de Montijo, wife of Napoleon III, as well as 105 photographs of the conflict that are archived at the KwaZulu Natal Museum, Pietermaritzburg and the Killie Campbell Museum, Durban. (Beyers 1981, 156-157).

24. (M. E. Barber 1962, 43).

25. See Chap. 6, Barber's theories.

26. The Graham's Town Journal, Wednesday, 22 April 1885, 3.

27. (M. E. Barber 1880, 193).

28. (M. E. Barber 1880, 203).

29. (M. E. Barber 1880, 202).

30. Barber, Wanderings, Vol. 2, MS 10560 (b), 53.

31. (McClintock 1995, 35).

32. (Porter 1876, 76, 77, 78).

33. As mentioned in Chap. 2.

34. Barber to J. M. Bowker, 10 March 1847, HM, SM 5325 (16).

35. See for example Sophia Beddoe, Diary: 1862-1864, CL, PR 7182, Thursday, 15 September 1864, 44. 
36. (Dubow 2006, 113, 115, 116).

37. (Dubow 2006, 208-210).

38. (Dubow 2006, 211).

39. (Dubow 2006, 210).

40. Barber, Wanderings, Vol. 1, MS 10560 (a), 11-12.

41. (M. E. Barber 1880, 200).

42. Barber, Wanderings, Vol. 1, MS 10560 (a), 43; Vol. 2, MS 10560 (b), 67, 71,85 .

43. Ibid., Vol. 1, MS 10560 (a), 11; 31.

44. Ibid., 38-39.

45. Barber, Wanderings, Vol. 1, MS 10560 (a), 10, 31. She uses the agricultural term 'harrow' to situate herself in her agricultural background and stress her superiority as someone who had by that time lived 59 years in the Cape.

46. Barber, Wanderings, Vol. 2, MS 10560 (b), 53, 56.

47. See for example (M. E. Barber 1903, 18); Barber, Wanderings, Vol. 3, MS 10560 (c), 104.

48. Barber, Wanderings, Vol. 3, MS 10560 (c), 101.

49. Ibid., Vol. 1, MS 10560 (a), 22-23; Vol. 3, MS 10560 (c), 91.

50. Ibid., Vol. 1, MS 10560 (a), 11.

51. (Dubow 2006, 95); (van Sittert 2003, 113-118, 2002, 102-112); (Lester $2001,86)$.

52. See (Cohen 1999).

53. Much of what follows on archaeology is taken from (Hammel 2018).

54. (I. Mitford-Barberton and Mitford-Barberton 1952, 175).

55. Three of his brothers had also financial difficulties. Western Cape Archives and Records Service, CSC 2/2/1/121, 1/11, January/February 1857, 12 January 1857, CSC $2 / 2 / 1 / 132,1.71$, Provisional Cases in the Supreme Court Oct to Dec 1859, William Heddingh L.L.D. versus Septimus Bouchier Bowker, Octavius Bourchier Bowker and John Henry Bowker (Summons), 12 December 1859 ended.

56. Message from His Excellency the Governor to the Honorable House of Assembly, transmitting

Copy of a Memorial from Mr. Thomas Holden Bowker. Printed by Order of the House of Assembly, 4 May 1858. CL: MS 18641.

57. For a sketch of Theopolis from 1836 see (The British Immigrants of $18201836,206)$.

58. For instance, in a pamphlet: (The British Immigrants of 1820 1836) HM [no archive number]. It was based on a series of articles that had already been published in the Zuid-Afrikaan Newspaper. (The British Immigrants of 18201836,208 ). See (Ross 1986, 78); (Jaffe 1994, 59).

59. See (Philip 1828). 
60. See (Elphick and Davenport 1997, 44-45).

61. (Lester 2001, 86).

62. CL: MS 18 641; Grey to Bowker, Morijah, 20 September 1858, quoted in: (I. Mitford-Barberton and Mitford-Barberton 1952, 177).

63. Edward John Morse's The Lower Albany Chronicle (1964), quoted in: (I. Mitford-Barberton 1970, 28).

64. The racist end to the quote was left out by Cohen in: (Cohen 1999, 123). This side-comment provides some insight into Bowker's racialised views and the Eurocentrism of The Journal of the Anthropological Institute of Great Britain and Ireland which printed this comment (Layard 1872, xcviii).

65. Letter in the Volks Blad, 12 September 1863 by S. J. J. van Tonder, D. F. van Tonder, L. J. van Tonder, J. Hendriks, G. J. van Tonder, J. E. de Wet and 22 others, quoted in: (I. Mitford-Barberton and Mitford-Barberton 1952, 178-179).

66. Layard to Owen, South African Museum, 14 April 1864, NHM, Letter 240, General Library: Owen Collection Layard, Edgar Leopold (18251900), England and South Africa. 14, 1 reply, and printed, February 1854-June 1884 and undated. 17/226-259; Suppl. 3.

67. Barber to T. H. Bowker, Highlands, 14 June 1865, HM, S.M.D. No 932; Barber's contributions to archaeology have hitherto only been mentioned in hagiographic articles. See for example (Cohen 1999) and encyclopaedic articles such as (Weedman 2001, 5, 27, 37).

68. (Dubow 2006, 65).

69. (Grey 1841, 261, 263-264). The argument that the Gwion Gwions-previously known as Bradshaw rock art-were painted by white people continues to be hotly debated. See for example: "A critique of Grahame Walsh's publication on the Gwion Gwion rock art of the Kimberley region", www.makinghistoryatmacquarie.wordpress.com/2011/11/22/ a-critique-of-grahame-walsh-publication-on-the-gwion-gwion-rock-artof-the-kimberly-region/, 22 November 2011, date accessed 16 April 2015.

70. Bowker to Grey, Tharfield (near Bathurst), 8 February 1869, National Library South Africa, Cape Town: Sir George Grey (Auckland) Collection, MSB 223, l (22) (75).

71. (Delaney 2009, 45); (Brantlinger 2003, 44).

72. Barber to T. H. Bowker, Highlands, 14 June 1865, HM, S.M.D. No 932.

73. (Dubow 2006, 110).

74. Barber to Roland Trimen, RES, Trimen Correspondence, Box 18, Letter 106, Vaal River, 29 April 1878. 
75. (Coetzee 1988, particularly Chapter 1), also see (Meskell and Weiss 2006, 89-90, 94, 95).

76. See for example (Burchell 1824a, b); (Dunn 1873).

77. Burchell, Travels, Vol. 2, 26, 29-30, 45, plate 4, quoted in (Wilson 1985, 1).

78. Quotes from (Deacon and Deacon 1999, 145-147). See (Deacon and Deacon 1999); See (Dunn 1873).

79. Barber, Wanderings, Vol. 1, MS 10560 (a), 28. In 1786, Sparrman had 'described the bored stone being used by Bushwomen to weigh a digging stick', but Barber does not mention this description. (Clark 1959, 24).

80. (M. E. Barber 1962, 52). 'These implements are to be met with in all parts of the world, scattered over its surface or buried beneath the soil, in the washings of rivers or the beds of lakes and caverns, [...].' (M. E. Barber 1871b, 39).

81. Barber, Wanderings, Vol. 1, MS 10560 (a), 5-6.

82. (Humphreys 1986, 4).

83. Barber to Roland Trimen, RES, Trimen Correspondence, Box 18, Letter 106, Vaal River, 29 April 1878. Warren has been called the ideological forefather of the Zionist state of Israel and a devoted advocate of Jewish colonisation. The 'Jewish Question', namely the perceived problem of Jewish belonging and the Jewish quest for a homeland, was widely discussed in Britain at the time. George Eliot's novel Daniel Deronda (1876), for instance, passionately appealed for the recreation of a Jewish polity and was widely read and debated in Britain and beyond (Friedman 1992, xxxviii); http://spikethenews.blogspot.ch/2014/02/founder-ofzionist-state-of-israel-sir.html, date accessed 5 April 2016.

84. Alfred Russel Wallace delivered this famous paper on The Origin of Human Races and the Antiquity of Man Deduced from the Theory of Natural Selection to a meeting of the Anthropological Society of London on 1 March 1864. It was printed in Volume 2 of the Society's Journal later in the same year. http://people.wku.edu/charles.smith/wallace/ S093.htm, date accessed 6 August 2015.

85. (Brantlinger 2003,26). 'At times, the indigenous community's very indigeneity is questioned. In these cases, they are perceived and treated as exogenous Others and become likely candidates for deportation (it is a recurrent phenomenon: black South Africans were thought to have entered the settler space after the Boer treks of the 1830s, and, in a different context, but in a similar fashion, Palestinians have also been represented as non-indigenous to Palestine; more generally, indigenous peoples - even Australian Aborigines - are frequently seen as "lost tribes" coming from somewhere else' (Veracini 2010, 25-26.). 
86. This had already been suggested by earlier writers, such as the Portuguese João dos Santos, See for example (Schütte 2013, 30-31).

87. "Vast Ruins in South Africa - The Ruined Cities of Mashonaland", The New York Times, 18 December 1892, 19.

88. (Pikirayi 2001, 9).

89. For his part, Mauch claimed that the Shona were of Jewish descent, a widespread trope to describe indigenous peoples in the settler colonial context. At the Cape, the amaXhosa were often analogised with the Jewish 'Other' in Europe, while it was also particularly common to talk of the Jewish descent of the amaZulu. Mauch, for instance, described a Shona sacrificial rite which resembled the prerequisites of a Jewish service. Barber and Bowker seem to have been familiar with Mauch's research, yet they never referred to the discussion that Africans could be of Jewish descent. Their interpretation also differed from that of settlers in Australia and the US who 'scientifically reconfigured' Aboriginal Australians or Native Americans 'as archaic, or simply dark, Caucasians'. Those European settlers who claimed the autochthonous population was of Jewish descent or even one of the lost tribes themselves tended to a justification of settlement via existing connections. Proto-Caucasian, Aryan-Maori or lost tribe theories allowed for the depiction of a historic continuity which concealed instances of blatant dispossession. See (Parfitt 2005, 56, 64, 67-68). 'Die Ähnlichkeit dieser Opfer mit jenen vom Israeltischen Kult vorgeschriebenen ist eine unverkennbare', (Petermann 1874, 51); (Anderson 2003, 6, also see: 193-194, 200-202, 204, 206); See (Jacobson 1998).

90. (Kuklick 1991, 139).

91. Bent 1896: xiv, 33, xiv, and passim, quoted in: (Kuklick 1991, 140, 142).

92. (Veracini 2010, 89).

93. (Veracini 2010, 90, 93).

94. (Johnston and Lawson 2000, 369).

95. (I. Mitford-Barberton and Mitford-Barberton 1952, 285-287). Barber to Roland Trimen, RES, Trimen Correspondence, Box 17, Letter 50, Highlands, 26 August 1866; '4 Bowker, O., Bloemfontein: Assegais, clubs, and shields of Basutos', Cape of Good Hope, Class XL, Paris Universal Exhibition of 1867: Catalogue of the British Section Containing a list of the exhibitors of the United Kingdom and its Colonies, and the Objects which they exhibit (London: Printed for her Britannic Majesty's commissioners and sold by spottiswoode and Co.), 267.

96. (Poignant 2004, 120); see also: (Thode-Arora 2014).

97. (Layland 1869).

98. (Layland 1869, 77-78). 
99. (J. H. Bowker 1872). He is also said to have collected Stone Age artefacts in the Maputo and Inhambane regions of Mozambique and near East London in the eastern part of the Cape Colony. See (Gooch 1881).

100. (Mitchell 1998, 16).

101. (Eldredge 1987, 68).

102. (J. H. Bowker 1884, 69-71).

103. (Saunders 1988, 19); (Theal 1889) digital print 2010, 295. It would be interesting to conduct further research on the discussion of cannibalism in the area.

104. (Bank 1996, 396-399).

105. Albany Natural History Society, The Graham's Town Journal, Friday, 13 September 1867.

106. Johann Friedrich Blumenbach introduced the term 'varieties', while Immanuel Kant did the same for 'race'. 'Race' was then adopted by Blumenbach, but both terms were common for a period. See for example: Immanuel Kant, "Of the Different Human Races", in (Bernasconi and Lott 2000, 8-22); Johann Friedrich Blumenbach, “On the Natural Variety of Mankind", in: (Bernasconi and Lott 2000, 27-37).

107. (Schär 2015, 225, 232, 234).

108. RES, Trimen Correspondence, Box 18, Letter 80, Highlands, 13 November 1870 .

109. See Mary E. Barber, "Lost”, in (M. E. Barber 1898, 119-123).

110. See for example: (Bank 1996); (Legassick and Rassool 2015); (Rassool 2015a); (Rassool 2015b); (Rassool 2012).

111. (Schinz 1891, 259 f.), my translation.

112. Hans Schinz to Julie Schinz-Vögeli, Amboland, Olukonda, 24 October 1885 , in (Beckmann 2012, 86), my translation.

113. (Beckmann 2012, 86-88).

114. See the following passage from Layard's autobiography, written ca. 1860-1861: 'the evening before we turned our faces homewards, wrapped them up in our "swag", \& strapped them on my back. We had not ridden far, when my host said "What is that strong aromatic smell, it seems to follow us" I then told him what I had done. "My heavens" he said "it was too bad of to get you to do this - if the natives of that tribe scent you, they will know what you have been at - rifling their dead, \& they will spear you to a certainty". We hurried on, however, \& got clear away, not falling in with any natives, \& I brought home my prizes in safety, but it is the last time I shall go on a "Head hunting" expedition; especially when the natives use these strong aromatic to embalm their dead.' Edgar Leopold Layard (1824-1900), Autobiography partial, http://en.wikisource.org/wiki/Edgar_Leopold_Layard_ Autobiography, date accessed 23 May 2015, pdf p. 10.

115. (M. E. Barber 1898, 95); (Mary E. Barber 1886, 10). 
116. (Mary E. Barber 1886, 10); (M. E. Barber 1898, 94-98).

117. Mary E. Barber to F. W. Barber, Malvern, 7 January 1891, Late Gareth Mitford-Barberton's Private Family Archive.

118. (Siveright 1877).

119. See (Bailie 1878). This was reprinted as a pamphlet in London in 1879.

120. (Mitford Barber 1892, 304).

121. (Mitford Barber 1892, 303).

122. (Mitford Barber 1892, 302-304).

123. (Raper 1989, 69).

124. (G. Mitford-Barberton 2006, 68).

125. (G. Mitford-Barberton 2006, 71).

126. (Henrichsen et al. 2015, 431-432).

127. See the JSAS special issue 41:3 (2015), edited by Dag Henrichsen, Giorgio Miescher, Ciraj Rassool and Lorena Rizzo, which emerged out of the conference 'Re-figuring the South African Empire', Basel, 9-11 September 2013.

128. (Clifford 1988).

129. (Hammel 2018, particularly 198-200).

\section{REFERENCES}

Anderson, Warwick. 2003. The Cultivation of Whiteness: Science, Health, and Racial Destiny in Australia. New York: Basic Books.

Bailie, Alexander Cumming. 1878. Report on the General Features of the Interior of South Africa, Between Barkly [West] and Gubuluwayo; to Accompany [a] Map of the Route. Journal of the Royal Geographical Society 48: 287-293.

Bank, Andrew. 1995. Liberals and Their Enemies: Racial Ideology at the Cape of Good Hope, 1820 to 1850. Unpublished PhD Dissertation, Cambridge University.

- 1996. Of 'Native Skulls' and 'Noble Caucasians': Phrenology in Colonial South Africa. Journal of Southern African Studies 22: 387-403.

- 1997. The Great Debate and the Origins of South African Historiography. The Journal of African History 38 (2): 261-281.

Barber, M.E. 187la. Night at Du Toit's Pan; Notes Form a Journal. Cape Monthly Magazine, 331-333.

- 1871b. In the Claims. Cape Monthly Magazine, 39-45.

- 1873. The Dark Races of the Diamond-Fields. Cape Monthly Magazine, 378-381.

- 1880. Locusts and Locust Birds. Transactions of the South African Philosophical Society 1: 193-218.

Barber, M. E. 1886. Egypt [Grahamstown, 24 May 1885]. The Royal Engineers Journal. 
Barber, M.E. 1898. The Erythrina Tree and Other Verses. London: Printed for Private Circulation.

- 1903. Stapelias. Kew Bulletin: 17-19.

- 1962. Wanderings in South Africa: An Account of a Journey from Kimberley to Cape Town and on to Natal. Quarterly Bulletin of the South African Museum 17: 39-53, 61-74, 103-116.

Beckmann, Gitte, ed. 2012. "Man muss eben Allessammeln". Der Zürcher Botaniker und Forschungsreisende Hans Schinz und seine ethnographische Sammlung Südwestafrika. Zürich: Verlag der Zürcher Zeitung.

Bernasconi, Robert, and Tommy L. Lott, eds. 2000. The Idea of Race. Indianapolis/ Cambridge: Hackett Publishing Company.

Beyers, C.J., ed. 1981. Dictionary of South African Biography. Vol. 4. Durban/ Pretoria: For Human Sciences Research Council by Butterworth \& Co.

Bowker, James H. 1872. Note on Perforated Stones. Cape Monthly Magazine 25: 55-57.

- 1884. Other Days in South Africa. Transactions of the South African Philosophical Society 3: 68-73.

Brantlinger, Patrick. 2003. Dark Vanishings: Discourse on the Extinction of Primitive Races, 1800-1930. Ithaca: Cornell University Press.

Burchell, William J. 1824a. Travels in the Interior of Southern Africa. Vol. 1. 2 vols. London: Longman, Hurst, Rees, Orme, Brown, and Green. https://doi. org/10.5962/bhl.title.109918.

- 1824b. Travels in the Interior of Southern Africa. Vol. 2. 2 vols. London: Longman, Hurst, Rees, Orme, Brown, and Green. https://doi.org/10.5962/ bhl.title.109918.

Clark, John Desmond. 1959. The Prehistory of Southern Africa: The Latest Discoveries About the Origins and Cultural History of Primitive Man in Southern Africa. Harmondsworth: Penguin Books.

Clifford, James. 1988. On Collecting Art and Culture. In The Predicament of Culture. Twentieth-Century Ethnography, Literature, and Art, 215-251. Cambridge, MA: Harvard University Press.

Coetzee, J.M. 1988. White Writing: On the Culture of Letters in South Africa. New Haven: Yale University Press.

Cohen, Alan. 1999. Mary Elizabeth Barber, the Bowkers and South African Prehistory. The South African Archaeological Bulletin 54: 120-127.

Crais, Clifton C. 1991. The Vacant Land: The Mythology of British Expansion in the Eastern Cape, South Africa. Journal of Social History XXV: 255-275.

Curthoys, Ann. 1997. Aboriginalphobia and Aboriginalphilia - Conflict and Ambivalence in Non-Aboriginal Australia. In The Resurgence of Racism: Howard, Hanson and the Race Debate, ed. Geoffrey Gray and Christine Winter, 138-146. Clayton: Monash Publications in History.

Deacon, Hilary J., and Janette Deacon. 1999. Human Beginnings in South Africa: Uncovering the Secrets of the Stone Age. Claremont: David Philip. 
Delaney, James J. 2009. Starting with Rousseau. London/New York: Continuum.

Dubow, Saul. 2006. Earth History and Evolutionism. In A Commonwealth of Knowledge: Science, Sensibility and White South Africa 1820-2000, ed. Saul Dubow. Oxford: Oxford University Press.

Dunn, Edward J. 1873. Through Bushmanland: Part 2. Cape Monthly Magazine 6: 31-42.

Eldredge, Elizabeth A. 1987. Drought, Famine and Disease in NineteenthCentury Lesotho. African Economic History 16: 61-93.

Elphick, Richard, and Rodney Davenport, eds. 1997. Christianity in South Africa: A Political, Social, and Cultural History. Berkeley/Los Angeles: University of California Press.

Eve, Jeanette. 2003. A Literary Guide to the Eastern Cape. Cape Town: Double Storey Books.

Friedman, Isaiah. 1992. The Question of Palestine: British-Jewish-Arab Relations: 1914-1918. 2nd, Expanded ed. New Brunswick/London: Transaction Publishers.

Godlonton, Robert. 1835. Introductory Remarks to a Narrative of the Interruption of the Kafir Hordes into the Eastern Province of the Cape of Good Hope. Grahamstown: Meurant and Godlonton.

- 1836. A Narrative of the Interruption of the Kaffir Hordes into the Eastern Province of the Cape of Good Hope, 1834-1835. Grahamstown: Meurant and Godlonton.

Gooch, W.D. 1881. Stone Age of South Africa. Journal of the Anthropological Institute 11: 124-182.

Grey, George. 1841. Journals of Two Expeditions of Discovery in North-West and Western Australia, During the Years 1837, 38, and 39, in 2 Vols., Vol. 1. London: T. and W. Boone.

Hammel, Tanja. 2018. The Politics and Production of History on the Birth of Archaeology at the Cape (1827-2015). In Science, Africa and Europe Processing Information and Creating Knowledge, ed. Martin Lengwiler, Nigel Penn, and Patrick Harries, 187-207. Abingdon-on-Thames: Routledge.

Henrichsen, Dag, Giorgio Miescher, Ciraj Rassool, and Lorena Rizzo. 2015. Rethinking Empire in Southern Africa. Journal of Southern African Studies 41: 431-435.

Humphreys, A.J.B. 1986. From Palestine to the Diamond Fields. The Digging Stick 3: 4-4.

Jacobson, Matthew Frye. 1998. Whiteness of a Different Color: European Immigrants and the Alchemy of Race. Cambridge, MA: Harvard University Press.

Jaffe, Hosea. 1994. European Colonial Despotism: A History of Oppression and Resistance in South Africa. London: Konak House.

Johnston, Anna, and Alan Lawson. 2000. Settler Colonies. In A Companion to Postcolonial Studies, ed. Henry Schwarz and Sangeeta Ray, 360-376. Malden: Blackwell. 
Kuklick, Henrika. 1991. Contested Monuments: The Politics of Archaeology in Southern Africa. In Colonial Situations: Essays on the Contextualization of Ethnographic Knowledge, ed. George W. Stocking, 135-169. Madison: University of Wisconsin Press.

Layard, Edgar L. 1872. Note on the Stone Implements of South Africa. The Journal of the Anthropological Institute of Great Britain and Ireland 1: xcvii-xcvic.

Layland, Mr. 1869. The Cave Cannibals of South Africa. Journal of the Ethnological Society of London 1: 76-80.

Legassick, Martin, and Ciraj Rassool. 2015. Skeletons in the Cupboard: South African Museums and the Trade in Human Remains, 1907-1917. Cape Town: Iziko Museums of SA.

Lester, Alan. 2001. Imperial Networks: Creating Identities in Nineteenth-Century South Africa and Britain. London/New York: Routledge.

McClintock, Anne. 1995. Imperial Leather: Race, Gender and Sexuality in the Colonial Contest. London: Routledge.

Merton, Robert K. 1963. Resistance to the Systematic Study of Multiple Discoveries in Science. European Journal of Sociology 4: 237-282.

- 1973. The Sociology of Science: Theoretical and Empirical Investigations. Chicago: The University of Chicago Press.

Meskell, Lynn, and Lindsay Weiss. 2006. Coetzee on South Africa's Past: Remembering in the Time of Forgetting. American Anthropologist 108: 88-99.

Mitchell, Peter. 1998. Archaeological Collections from the Anglo-Zulu War in the Collections of the British Museum. Southern African Field Archaeology 7: 12-19.

Mitford Barber, Henry. 1892. The Perforated Stones of South Africa. The Journal of the Anthropological Institute of Great Britain and Ireland 21.

Mitford-Barberton, Ivan. 1970. Comdt. Holden Bowker. An 1820 Settler Book Including Unpublished Records of the Frontier Wars. Cape Town/Pretoria: Human and Rousseau.

Mitford-Barberton, Gareth. 2006. Pioneer Spirit. Victoria: Trafford Publishing.

Mitford-Barberton, Ivan, and Raymond Berners Mitford-Barberton. 1952. The Bowkers of Tharfield. Oxford: Oxford University Press.

Parfitt, Tudor. 2005. The Use of the Jew in Colonial Discourse. In Orientalism and the Jews, ed. Ivan Davidson Kalmar and Derek J. Penslar, 51-67. Waltham: Brandeis University Press.

Petermann, Dr. A. 1874. Karl Mauch's Reisen im Inneren von Süd-Afrika 1865-1872. Mittheilungen aus Justus Perthes' Geographischer Anstalt über wichtige neue Erforschungen auf dem Gesammtgebiete der Geographie Ergänzungsheft 37.

Philip, Rev. John. 1828. Researches in South Africa; Illustrating the Civil, Moral, and Religious Condition of the Native Tribes: Including Journals of the Author's Travels in the Interior; Together with Detailed Accounts of the Progress of Christian 
Missions, Exhibiting the influence of Christianity in Promoting Civilization. 2 Vols. London: James Duncan.

Pikirayi, Innocent. 2001. The Zimbabwe Culture: Origins and Decline of Southern Zambezian States. Walnut Creek/Lanham/New York/Oxford: AltaMira Press. Poignant, Roslyn. 2004. Professional Savages: Captive Lives and Western Spectacle. New Haven/London: Yale University Press.

Porter, William. 1876. On Scholastic and Philosophic Studies. Cape Monthly Magazine, 13.

Raper, Peter E. 1989. Dictionary of Southern African Place Names. Johannesburg: Jonathan Ball Publishers.

Rassool, Ciraj. 2012. Knochengedächtnis. Menschliche Überreste, Recht und National Heritage in Südafrika. In Biohistorische Anthropologie: Knochen, Körper und DNA in Erinnerungskulturen, ed. Gesine Krüger and Marianne Sommer, 164-199. Berlin: Kadmos Kultuverlag.

- 2015a. Re-storing the Skeletons of Empire: Return, Reburial and Rehumanisation in Southern Africa. Journal of Southern African Studies 41: 653-670.

- 2015b. Human Remains, the Disciplines of the Dead, and the South African Memorial Complex. In The Politics of Heritage in Africa: Economies, Histories, and Infrastructures, ed. Derek Peterson, Kodzo Gavua, and Ciraj Rassool, 133-156. Cambridge: Cambridge University Press.

Ross, Andrew. 1986. John Philip 1775-1851: Missions, Race and Politics in South Africa. Aberdeen: University Press.

Saunders, Christopher. 1988. The Making of the South African Past: Major Historians on Race and Class. Totowa: Barnes \& Noble Books.

Schär, Bernhard C. 2015. Tropenliebe: Schweizer Naturforscher und niederländischer Imperialismus in Südostasien um 1900. Frankfurt/New York: Campus Verlag.

Schinz, Hans. 1891. Deutsch-Südwest-Afrika. Forschungsreisen durch die deutschen Schutzgebiete Gross-Nama- und Hereroland, nach dem Kunene, dem Ngami-See und der Kalahari: 1884-1887. Oldenburg: Sulze'sche Hof-Buchhandlung.

Schütte, Michael. 2013. Die „Entdeckung der Ruinen von Zimbaoe“: Zur Erfindung „weißer Geschichte“ in „Schwarzafrika“ 1871-1872. Magisterarbeit, Göttingen: Seminar für Mittlere und Neuere Geschichte, Philosophische Fakultät, Georg-August-Universität Göttingen.

van Sittert, Lance. 2002. From 'Mere Weeds' and 'Bosjes' to a Cape Floral Kingdom: The Re-Imagining of Indigenous Flora at the Cape, c. 1890-1939. Kronos 28: 102-126.

- 2003. Making the Cape Floral Kingdom: The Discovery and Defence of Indigenous Flora at the Cape ca. 1890-1939. Landscape Research 28: 113-129. Siveright, Mr. 1877. A Trans-African Telegraph. Transactions of the South African Philosophical Society 1: 1-11. 
The British Immigrants of 1820. 1836. Some Reasons for Our Opposing the Author of the "South African Researches" The Rev. John Philip, D. D. (Aberdeen), Superintendent of the London Society's Mission in South Africa. Cape Town/ Grahamstown/London: A. S. Robertson, Godlonton, J. M. Richardson.

Theal, George McCall. 1889. History of South Africa Since September 1795. 5 Vols. Cambridge: Cambridge University Press.

Thode-Arora, Hilke. 2014. From Samoa with Love? Samoa-Völkerschauen im Deutschen-Kaiserreich - eine Spurensuche. München: Hirmer Verlag.

Tylden, Geoffrey. 1950. The Rise of the Basuto. Cape Town: Juta \& Co.

Veracini, Lorenzo. 2010. Settler Colonialism: A Theoretical Overview. Basingstoke/ New York: Palgrave Macmillan.

Weedman, Kathryn. 2001. Who's 'That Girl': British, South African, and American Women as Africanist Archaeologists in Colonial Africa (1860s-1960s). African Archaeological Review 18: 1-47.

Wilson, M.L. 1985. Bored Stones - First Hand Evidence on Record. The Digging Stick 2: 1-1.

Open Access This chapter is licensed under the terms of the Creative Commons Attribution 4.0 International License (http://creativecommons.org/licenses/ by $/ 4.0 /$ ), which permits use, sharing, adaptation, distribution and reproduction in any medium or format, as long as you give appropriate credit to the original author(s) and the source, provide a link to the Creative Commons licence and indicate if changes were made.

The images or other third party material in this chapter are included in the chapter's Creative Commons licence, unless indicated otherwise in a credit line to the material. If material is not included in the chapter's Creative Commons licence and your intended use is not permitted by statutory regulation or exceeds the permitted use, you will need to obtain permission directly from the copyright holder.

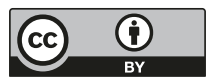

